\title{
KEDUDUKAN AHLI WARIS TERHADAP HARTA WARISAN SESEORANG YANG DIDUGA MENINGGAL DUNIA (KEADAAN TIDAK HADIR)
}

\author{
Haryadi Sutanto \\ Fakultas Hukum, Universitas Narotama, Surabaya \\ e-mail: haryadi.sutanto@gmail.com \\ Henny Tanuwidjaja \\ Fakultas Hukum, Universitas Narotama, Surabaya \\ e-mail: dr_hennytan_notaris@yahoo.com
}

\begin{abstract}
ABSTRAK
Hukum kewarisan nasional yang dicita-citakan dan yang sedang direncanakan dewasa ini bersumber pada Hukum Islam, Hukum Adat, dan Hukum Perdata. Adapun tujuan dari penulisan ini adalah untuk mengetahui cara penetapan, kedudukan dan akibat hukum dari orang yang diduga meninggal dunia atau si yang tidak hadir atau afwezigheid, serta perlindungan hukum untuk ahli warisnya menurut Hukum Perdata. Penetapan oleh Pengadilan Negeri tentang afwezigheid dalam perspektif Hukum Waris Perdata, yaitu mereka sebagai ahli waris yang berkepentingan, apabila 5 (lima) tahun telah lewat semenjak kepergian si yang tidak hadir dari tempat tinggalnya, dapat mengajukan permohonan kepada Pengadilan Negeri. Pengadilan Negeri akan memeriksa dan melakukan pemanggilan kepada si yang tidak hadir, dan apabila si yang tidak hadir tidak datang/hadir tanpa memberi kuasa kepada seorang wakil, maka Pengadilan Negeri akan melakukan pemanggilan secara umum dalam jangka waktu selama sedikitnya 3 (tiga) bulan (Pasal 467 BW). Jika si yang tidak hadir/wakilnya tetap tidak hadir, maka Pengadilan Negeri akan menetapkan bahwa si yang tidak hadir diduga telah meninggal dunia. Dengan penetapan itulah ahli waris dapat menguasai harta warisan dari si yang tidak hadir dan jika diperlukan saat itu yang ditinggalkan dapat melangsungkan perkawinan yang baru dengan orang lain (Pasal 495 BW).
\end{abstract}

Kata Kunci: Hukum Waris Perdata, Keadaan Tidak Hadir

\begin{abstract}
The intended national and planned legacy of national heritage is based on Islamic Law, Customary Law and Civil Law (Burgerlijk Wetboek). The purpose of this paper is to know how the determination, position and legal consequences of the allegedly dead or the absent (afwezigheid), as well as legal protection for his heirs according to Civil Law. The determination by the District Court of "afwezigheid" in the perspective of the Inheritance Law of the Inheritance of the Inheritance of the Inherited Law, if 5 (five) years have passed since the departure of the absent from his residence, may apply to the District Court. The District Court shall examine and call to the absentee, and if the absentee does not appear / present without authorizing a representative, the District Court shall make a general summonment for a period of at least 3 (three) months $(467 \mathrm{BW})$. If the absentee is not present, the District Court will determine that the absentee is suspected to have died. It is by this determination that the heirs can control the inheritance of the absentee and, if necessary, the moment left behind, may establish a new marriage with another person $(495 \mathrm{BW})$.
\end{abstract}

Keywords: Law of Civil Inheritance, Afwezigheid

\section{PENDAHULUAN}

Banyaknya Tenaga Kerja Indonesia (TKI) yang bekerja di negara-negara lain, atau barangkali terhadap seseorang lain yang telah pergi lebih dari 5 (lima) tahun tanpa meninggalkan pesan/wakil dapat menimbulkan banyak masalah yang akan terjadi, salah satunya permasalahan yang akan dibahas dalam penulisan ini adalah masalah afwezigheid terhadap warisan TKI atau seseorang lain, apabila ia 
meninggalkan keluarganya dan tidak kembali dalam jangka waktu lebih dari 5 (lima) tahun (Pasal 467 Burgerlijk Wetboek atau BW), jika "si yang tidak hadir" tersebut meninggalkan warisan, maka harta warisan tersebut akan menimbulkan permasalahan hukum terhadap para ahli warisnya.

Dengan kondisi seperti di atas maka ada kemungkinan bahwa seseorang tersebut pergi dan tidak ada kabar dalam jangka waktu 5 (lima) tahun telah lewat setelah keberangkatannya dari tempat tinggalnya dan tidak pernah terdapat tanda-tanda tentang masih hidup atau telah meninggal (Pasal 467 BW) dan atau 5 (lima) tahun setelah diperoleh kabar terakhir yang membuktikan bahwa saat itu ia masih hidup (Pasal 468 BW). Hal ini menimbulkan suatu akibat hukum khususnya dalam hukum waris menurut Kitab Undang-Undang Hukum Perdata (BW) untuk mengalihkan hak-hak atas nama "si yang tidak hadir" tersebut kepada ahli warisnya, apabila kepentingan ahli waris untuk menguasai/mengalihkan harta dan atau untuk melangsungkan pernikahan (bagi duda/ janda yang ditinggalkan) dengan pihak lain demi melanjutkan kehidupannya karena dalam perkawinan dalam BW sendiri menggunakan asas Monogami.

Perlu diketahui bahwa di Indonesia berlaku 3 (tiga) hukum yang mengatur mengenai hukum waris, yaitu Hukum Waris Adat, Hukum Waris Islam, dan Hukum Waris Perdata. Menurut Pasal 163 IS (Indische Staatsregeling) penduduk Indonesia terbagi menjadi 3 Golongan penduduk, yaitu: Warga Negara Indonesia Asli (Bumiputera); Warga Negara Indonesia Timur Asing, yang terdiri dari Timur Asing Keturunan Tiong Hoa, dan Timur Asing bukan keturunan Tiong Hoa (Arab India, dan lainlain yang menundukan diri); Warga Negara Indonesia keturunan Eropa. ${ }^{1}$ Sedangkan Undang-Undang Kewarganegaraan mengatur tentang syarat-syarat dan ketentuan bagi warga negara yang ingin masuk menjadi Warga Negara Indonesia.

Dengan melihat adanya perbedaan golongan tersebut, maka dapat disimpulkan bahwa hukum waris Perdata berlaku untuk golongan warga negara: Pertama, Bagi orang-orang Indonesia asli (Bumiputera) pada pokoknya berlaku hukum adatnya yang berlaku di berbagai daerah yang sesuai dengan kebudayaan masing-masing daerah, bagi warga

\footnotetext{
${ }^{1}$ Henny Tanuwidjaja, Hukum Waris Menurut $B W$, Refika Aditama, Bandung, 2012, h. 1.
}

negara Indonesia yang beragama Islam terdapat pengaruh nyata dari hukum Islam. Kedua, Bagi Golongan Timur Asing: a. Timur Asing keturunan Tiong Hoa, berdasarkan Staatsblad 1917-129, berlaku hukum waris Perdata (Buku II Titel 12 sampai dengan 18, Pasal 830-1130), b. Timur Asing Lainnya (India, Arab, dan lain-lain) berlaku hukum waris adat mereka masing-masing yang tumbuh dan berkembang di Indonesia, kecuali untuk wasiat umum berdasarkan Staatsblad 1924-556 tunduk pada BW. Ketiga, Bagi Golongan Eropa tunduk pada hukum waris BW. ${ }^{2}$

Menurut Henny Tanuwidjaja dalam bukunya yang berjudul Hukum Waris Menurut BW, mengemukakan bahwa: Hukum Waris adalah hukum yang mengatur mengenai apa yang terjadi dengan harta kekayaan seseorang yang meninggal dunia, atau hal-hal yang mengatur tentang peralihan hak harta kekayaan pewaris yang meninggal dunia serta akibat hukumnya bagi ahli waris, yang dapat diwariskan hanya (hak-hak dan kewajiban di bidang hukum kekayaan saja) dengan mengingat kapan warisan terbuka yang diatur dalam Pasal $830 \mathrm{BW}$, yaitu: Ada pewaris yang meninggal dunia; Pewaris meninggalkan harta warisan; Ahli waris telah ada pada saat warisan jatuh meluang (Pasal $836 \mathrm{BW}){ }^{3}$

Sedangkan menurut pendapat Tamakiran, hukum waris BW diartikan sebagai, Kesemuanya kaedah hukum yang mengatur kekayaan seseorang setelah ia meninggal dunia dan menentukan siapa orangnya yang dapat menerimanya. ${ }^{4}$ Pewarisan akan dilaksanakan setelah ada seseorang yang meninggal dunia dengan meninggalkan harta kekayaan dan ada ahli waris yang berhak atas harta peninggalan tersebut, sebagaimana mulai terhitung sejak meninggalnya pewaris, maka hak dan kewajibannya demi hukum akan beralih kepada para penerima waris. Dengan demikian, berdasarkan ketentuan Pasal $834 \mathrm{BW}$, penerima waris berhak menguasai kekayaan pewaris atau boedel berlandaskan pada haknya sebagai penerima waris dari pewaris. Sedangkan dalam Pasal 836 BW berbunyi, Dengan mengingat akan ketentuan dalam Pasal 2 Kitab ini, supaya dapat bertindak sebagai waris, seseorang

\footnotetext{
${ }^{2}$ Ibid.

${ }^{3}$ Ibid., h. 2.

4 Tamakiran, Asas-Asas Hukum Waris, Pionir Jaya, Bandung, 1992, h. 24.
} 
harus telah ada, pada saat warisan jatuh meluang, dari ketentuan tersebut dapat diketahui bahwa ahli waris juga harus telah ada (masih hidup) pada saat harta warisan terbuka.

Menurut Pasal 830 BW pewarisan terjadi apabila pewaris meninggal dunia atau afwezigheid, apabila pewaris tidak diketahui keberadaannya dan kabarnya apakah masih hidup atau tidak, bagaimana dengan harta warisannya? Keadaan tidak hadir atau afwezigheid mempengaruhi dan memberi akibat hukum kepada yang bersangkutan sendiri dan kepada pihak keluarga yang ditinggalkan. Dalam keadaan tidak hadir afwezigheid, cara mewaris dapat berdasarkan: mewaris berdasarkan Undang-Undang atau $A b$ Intestato yaitu dengan dasar kedudukan sendiri berdasarkan golongan ahli waris (Pasal 852$861 \mathrm{BW}$ ) dan atas dasar pergantian tempat (Pasal 841 BW); atau mewaris berdasarkan testament atau surat wasiat (Pasal $875 \mathrm{BW}$ ).

Pengaruh keadaan tidak hadir itu adalah: Penyelenggaraan kepentingan yang bersangkutan, dan Status hukum yang bersangkutan sendiri, atau status hukum anggota keluarga yang ditinggalkan mengenai pewarisan dan perkawinan.

\section{RUMUSAN MASALAH}

Dari uraian di atas, maka timbul permasalahan yang perlu dibahas, yaitu perlindungan hukum ahli waris terhadap pewaris dalam keadaan afwezigheid, serta akibat hukum kembalinya seseorang dalam keadaan afwezigheid terhadap harta perkawinan.

\section{METODE PENELITIAN}

Penelitian hukum ini menggunakan pendekatan undang-undang, yakni menggunakan peraturan perundang-undangan yang relevan untuk memecahkan isu hukum yang diajukan.

\section{PEMBAHASAN}

\section{Perlindungan Hukum Ahli Waris Terhadap Pewaris dalam Keadaan Afwezigheid}

Kata perlindungan menurut Kamus Umum Bahasa Indonesia berarti tempat berlindung atau merupakan perbuatan (hal) melindungi, misalnya memberi perlindungan kepada orang yang lemah. Sedangkan hukum menurut Sudikno Mertokusumo, yaitu kumpulan peraturan atau kaedah yang mempunyai isi yang bersifat umum dan normatif, umum karena berlaku bagi setiap orang dan normatif karena menentukan apa yang seyogyanya dilakukan, apa yang tidak boleh dilakukan atau harus dilakukan serta menentukan bagaimana caranya melaksanakan kepatuhan kepada kaedah-kaedah. ${ }^{5}$

Sedangkan menurut Philipus M. Hadjon bahwa perlindungan hukum dalam kepustakaan hukum berbahasa Belanda dikenal dengan sebutan rechtbescherming van de burfer. Perlindungan hukum bagi rakyat ada 2 (dua) macam, yaitu: pertama, Perlindungan Hukum represif, artinya ketentuan hukum dapat dihadirkan sebagai upaya pencegahan terhadap tindakan pelanggaran hukum. Upaya ini diimplementasikan dengan membentuk aturan hukum yang bersifat normatif; kedua, Perlindungan hukum preventif, artinya ketentuan hukum untuk mencegah terjadinya sengketa, yang mengarahkan tindakan pemerintah bersikap hati-hati dalam pengambilan keputusan berdasarkan diskresi. Perlindungan hukum yang represif bertujuan menyelesaikan terjadinya sengketa, termasuk penanganannya di lembaga peradilan. ${ }^{6}$

Prinsip perlindungan hukum bagi rakyat di Indonesia menurut Philipus M. Hadjon adalah prinsip pengakuan dan perlindungan terhadap harkat dan martabat manusia yang bersumber pada Pancasila dan prinsip negara hukum yang berdasarkan Pancasila. Pengakuan dan perlindungan terhadap harkat dan martabat manusia dikatakan bersumber pada Pancasila, karena pengakuan dan perlindungan terhadapnya secara intrinsik melekat pada Pancasila dan seyogyanya memberi warna dan corak serta isi negara hukum yang berdasarkan Pancasila. ${ }^{7}$

Perlindungan hukum berdasarkan Pancasila berarti pengakuan dan perlindungan hukum akan harkat dan martabat manusia atas dasar nilai Ketuhanan Yang Maha Esa, Kemanusiaan, Persatuan, Permusyawaratan dan Keadilan Sosial. Nilai-nilai tersebut melahirkan pengakuan dan perlindungan hak asasi manusia dalam wadah negara kesatuan yang menjunjung tinggi semangat kekeluargaan dalam mencapai kesejahteraan bersama.

\footnotetext{
5 Sudikno Mertokusumo, Mengenal Hukum (Suatu Pengantar), Liberty, Yogyakarta, 1991, h. 38.

${ }^{6}$ Philipus M.Hadjon, Perlindungan Hukum Bagi Rakyat Indonesia, Bina Ilmu, Surabaya, 1987, h. 25.

${ }^{7}$ Ibid, h. 37.
} 
Setelah mengetahui arti dari kata perlindungan dan kata hukum itu sendiri maka penulis mengartikan bahwa, perlindungan hukum adalah suatu perbuatan hal melindungi subjek-subjek hukum dengan peraturan perundang-undangan yang berlaku dan pelaksanaannya dapat dilaksanakan sesuai kaidah hukumnya.

Sedangkan untuk hal keadaan tidak hadir atau afwezigheid sendiri telah diatur dalam pasal-pasal dalam BW mulai Pasal 463 sampai dengan Pasal 495, yang dapat digunakan sebagai dasar hukum untuk membahas apa yang dimaksud dengan keadaan tidak hadir.

Mendasarkan pada pendapat R. Soetojo Prawirohamidjojo dan Marthalena Pohan, Pasal 463 BW memberikan penjelasan bahwa ketidakhadiran seseorang harus memenuhi unsur-unsur sebagai berikut: Meninggalkan tempat kediamannya; Tanpa memberikan kuasa kepada orang lain guna mewakilinya; Tidak menunjuk atau memberikan kuasa kepada orang lain untuk mengurus kepentingannya; Kuasa yang pernah diberikan telah gugur; Jika timbul keadaan yang memaksa untuk menanggulangi pengurusan harta bendanya secara keseluruhan atau sebagian; Untuk mengangkat seorang wakil, harus diadakan tindakan-tindakan hukum untuk mengisi kekosongan sebagai akibat ketidakhadiran tersebut; Mewakili dan mengurus kepentingan orang yang tidak hadir, tidak hanya meliputi kepentingan harta kekayaannya saja, melainkan juga untuk kepentingan-kepentingan pribadinya. Sebagai contoh misalnya, bertindak sebagai wakil dalam suatu proses perceraian, baik sebagai penggugat ataupun tergugat. ${ }^{8}$

Ketentuan-ketentuan di atas berlaku sah dengan perubahan-perubahan yang ada. Sebagai contoh, terhadap orang-orang yang belum dapat dipastikan apakah telah meninggalkan tempat tinggalnya serta tidak dapat diketahui dengan pasti mengenai keberadaanya (terjadi bencana alam atau peperangan, dan sebagainya). Dalam BW dikenal ada 3 masa atau 3 tingkatan keadaan tidak hadir seseorang, yaitu:

Pertama, Masa Tindakan Sementara (Pasal 463-465 BW). Masa ini diambil jika ada alasanalasan yang mendesak untuk mengurus seluruh atau

${ }^{8}$ R. Soetojo Prawirohamidjojo dan Marthalena Pohan, Hukum Orang dan Keluarga (Personen En Familie-Recht), Airlangga University Press, Surabaya, 2000, h. 242. sebagian harta kekayaannya. Tindakan sementara ini dimintakan kepada Pengadilan Negeri oleh orang yang mempunyai kepentingan terhadap harta kekayaan si yang tidak hadir. Misalnya istrinya dapat memohon tindakan sementara tersebut. Tindakan ini dapat diambil, para kreditur, sesama pemegang saham, dan lain-lain, juga jaksa dengan syarat-syarat, sebagai berikut: a. Orang yang bersangkutan tidak ada di tempatnya; b. Orang yang bersangkutan tidak melakukan sendiri pengaturan urusan-urusannya sendiri; c. Tindakan-tindakan yang sudah diambilnya, seperti pemberian kuasa kepada orang kepercayaannya sudah gugur. ${ }^{9}$ Tindakantindakan sementara yang dimaksud itu mulai dengan perintah hakim kepada Balai Harta Peninggalan untuk mengurus seluruh atau sebagian harta serta kepentingan orang yang tidak hadir, selanjutnya untuk mewakili serta mempertahankan hak-hak orang yang tidak hadir.

Kedua, Masa Adanya Kemungkinan Sudah Meninggal Dunia (Pasal 467-470 BW). Seseorang dapat diputuskan "kemungkinan" sudah meninggal dunia, jika: a. Tidak hadir 5 (lima) tahun, apabila tidak meninggalkan surat kuasa, dimulai pada hari ia pergi tidak ada kabar yang diterima dari orang tersebut atau sejak kabar terakhir diterima (Pasal $467 \mathrm{BW}$ ); b. Tidak hadir 10 (sepuluh) tahun, bila surat kuasa ada tetapi sudah habis berlakunya, dimulai pada hari ia pergi tidak ada kabar yang diterima dari orang tersebut atau sejak kabar terakhir diterima (Pasal 470 BW); c. Tidak hadir 1 (satu) tahun, bila orangnya termasuk awak atau penumpang kapal laut atau pesawat udara, dimulai sejak adanya kabar terakhir dan jika tidak ada kabar sejak hari keberangkatannya (Staatsblad 1922 No. 455); d. Tidak hadir 1 (satu) tahun, jika orangnya hilang pada suatu peristiwa fatal yang menimpa sebuah kapal laut atau pesawat udara, dimulai sejak tangga terjadinya peristiwa tersebut (Staatsblad 1922 No. 455); e. Dalam Peraturan Pemerintah No. 9 Tahun 1975, dikatakan bahwa apabila salah satu pihak meninggalkannya 2 tahun berturut-turut, pihak yang yang ditinggalkan boleh mengajukan perceraian. ${ }^{10}$

\footnotetext{
${ }^{9}$ Ibid., h. 244.

${ }^{10}$ Henny Tanuwidjaja, "Pewarisan Afwezigheid/Keadaan Tidak Hadir dan Pewarisan Perkawinan Kedua Menurut Hukum Perdata Barat (BW)", Naskah Jurnal Hukum, yang diterbitkan Universitas Katholik Satya Wacana, 2016, h. 10-11. (selanjutnya disebut dengan Henny Tanuwidjaja 2).
} 
Mendasarkan pada pendapat J. Satrio, keadaan tidak hadir tersebut tidak dapat dikatakan langsung mempengaruhi kedudukan hukum seseorang, karena orang yang tidak hadir, selama ia masih hidup, masih tetap mempunyai kewenangan hukum dan cakap bertindak. Untuk timbulnya akibat hukum tertentu bahkan disyaratkan jangka waktu 5 (lima) atau 10 (sepuluh) tahun. ${ }^{11}$

Keadaan kemungkinan sudah meninggal berakhir apabila: Jika orang yang tidak hadir kembali atau ada kabar baru tentang hidupnya; Jika orang yang tidak hadir meninggal dunia; Jika masa pewarisan definitif termaksud dalam Pasal 484 BW dimulai.

Ketiga, masa pewarisan definitif seperti yang dimaksud dalam huruf (c) di atas terjadi apabila lewat 30 (tiga puluh) tahun sejak tanggal tentang "mungkin sudah meninggal dunia" atas keputusan hakim, atau setelah lewat 100 (seratus) tahun setelah lahirnya orang yang tidak hadir, maka terbebaslah sekalian penanggung, sedangkan pembagian kekayaan ditinggalkan, sekedar ini telah berlangsung, tetap berlaku, atau jika belum berlangsung, para ahli waris boleh mengadakan pembagian yang tetap atas harta peninggalan (Pasal 484 BW). Dengan kata lain setelah 30 tahun tidak ada kabar dari orang yang tidak hadir maka warisan dapat langsung dibagikan kepada semua ahli waris tanpa persetujuan orang yang tidak hadir tersebut atau 100 tahun setelah lahirnya orang yang tidak hadir tersebut.

Dari ketentuan di atas maka dapat diketahui apabila ahli waris yang ditinggalkan, setelah lewat 5 (lima) tahun semenjak kepergian si pewaris atau terdengar kabar tentangnya, maka ahli waris tersebut mempunyai hak untuk dapat mengajukan permohonan penetapan pengadilan tentang afwezigheid ke Pengadilan Negeri (Pasal 468 BW), untuk menguasai harta yang ditinggalkan oleh si yang tidak hadir. Penetapan pengadilan yang dikeluarkan oleh pengadilan setempat adalah suatu bentuk perlindungan hukum yang diberikan untuk ahli waris dari si pewaris yang mengalami keadaan afwezigheid.

Sedangkan kedudukan orang hilang menurut Hukum Waris Islam Al-Mafqud, para ulama sepakat bahwa orang hilang tetap dianggap masih hidup selama masa hilangnya dan karenanya harta miliknya

11 J. Satrio, Hukum Pribadi Bagian 1 Persoon Alamiah, Citra Aditya Bakti, Bandung, 1999, h. 206. tidak dapat dibagikan kepada ahli waris dan juga istrinya tetap status sebagai istri. Tentang sampai kapan orang hilang dinyatakan dalam status orang hidup itu, terjadi perbedaan pendapat dikalangan ulama dan bila ia hilang dalam kondisi yang sangat mudah menimbulkan kematian seperti dalam peperangan atau kecelakaan yang menyebabkan tewasnya sebagian besar korban dan dalam kondisi biasa yang kecil kemungkinan timbul kematian seperti dalam perjalanan bisnis atau menuntut ilmu. Dalam kondisi pertama, seseorang yang hilang ditunggu selama 40 tahun; kalau tidak kembali dalam waktu itu harta dapat dibagikan dan istrinya masuk dalam iddah wafat. Tetapi dalam keadaan kedua, maka ia harus ditunggu sebagaimana yang ditetapkan oleh jumhur ulama. ${ }^{12}$

\section{Akibat Hukum Kembalinya Seseorang Dalam Keadaan Afwezigheid Terhadap Harta Perkawinan}

Dengan diundangkannya Undang-Undang Nomor 1 Tahun 1974 tentang Perkawinan (selanjutnya disingkat UU Perkawinan), yang berlaku bagi seluruh rakyat di wilayah Indonesia. Di dalam Pasal 66 UU Perkawinan sebagai ketentuan penutup menyebutkan, Untuk perkawinan dan segala sesuatu yang berhubungan dengan perkawinan berdasarkan UU Perkawinan dan dengan berlakunya undangundang ini, maka ketentuan-ketentuan yang diatur dalam KUHPerdata atau BW, Ordonasi Perkawinan Indonesia Kristen (HOCI), dan peraturan-peraturan lain yang mengatur tentang perkawinan sejauh telah diatur dalam undang-undang ini, dinyatakan tidak berlaku.

Dari ketentuan di atas maka R. Soetojo Prawirohamidjojo dan Marthalena Pohan berpendapat, yaitu BW tetap berlaku sejauh undang-undang tersebut tidak mengatur hal-hal yang berhubungan dengan perkawinan. Mengenai perkawinan yang dimaksud disini adalah perkawinan yang terbatas bagi warga negara Indonesia saja, sedangkan bagi orang asing yang termasuk golongan Eropa atau Timur Asing Tionghoa masih tetap diatur dalam

${ }^{12}$ Imam Asari, "Kedudukan Orang Hilang Dalam Perspektif Kewarisan KUHPerdata (BW) dan Hukum Kewarisan Islam", Jurnal Ilmiah, Fakultas Hukum Universitas Mataram 2012. 
BW. ${ }^{13}$ Sepanjang WNI Keturunan tersebut masih tunduk pada Undang-Undang Kewarganegaraan Indonesia maka tetap menggunakan Hukum Perdata Indonesia.

Perkawinan dalam BW mendasarkan pada asas monogami, yang artinya dalam waktu yang sama seorang pria hanya diperbolehkan mempunyai seorang istri, dan seorang wanita hanya boleh mempunyai seorang suami (Pasal $27 \mathrm{BW}$ ), sehingga dalam BW tidak diperbolehkan seseorang untuk melangsungkan perkawinan lagi selama ia masih terikat perkawinan lama.

Menurut Djamil Latif, akibat dari afwezigheid terhadap perkawinan adalah sebagai berikut: pertama, Apabila pemanggilan itu tidak berhasil, maka menurut Pasal 494 BW, Pengadilan Negeri dapat mengizinkan suami atau istri yang ditinggalkan itu untuk kawin dengan orang lain. Dengan perkawinan baru ini menurut angka 2 Pasal 199 BW, perkawinan yang lama dianggap terputus; kedua, Apabila orang yang berpergian itu kembali atau ada kabar tentang masih hidupnya sebelum diadakan perkawinan baru oleh yang ditinggalkan, maka menurut Pasal 495 BW, izin Pengadilan Negeri untuk melakukan perkawinan lagi itu secara hukum tidak berlaku lagi. Akan tetapi apabila perkawinan baru itu terlanjur dilakukan, maka menurut ayat (2) Pasal 495 BW, perkawinan tersebut tidak bisa dibatalkan. Orang yang berpergian itu dapat juga kawin dengan orang lain. ${ }^{14}$

Izin dari pengadilan yang dimaksud yaitu penetapan pengadilan, yang secara hukum merupakan perwakilan dari si yang tidak hadir untuk memberikan persetujuan kepada pasangan yang ditinggalkan untuk menikah kembali. Selain dapat memutus keadaan afwezigheid, Pengadilan Negeri juga dapat menangguhkan keputusan afwezigheid selama 5 (lima) tahun lagi apabila saksi-saksi atau pewartaan di surat kabar dirasa belum cukup.

Sejak saat dilangsungkan perkawinan antara suami-istri secara hukum atau van rechtswege, maka sejak saat itulah terjadilah kebersamaan (kebulatan) harta perkawinan sejauh dalam perkawinan tersebut tidak ada perjanjian kawin atau hufelijks voorwaden. Meskipun ada kebersamaan harta secara bulat,

${ }^{13}$ R. Soetojo Prawirohamidjojo dan Marthalena Pohan, Op.Cit., h. 2.

${ }^{14}$ Djamil Latif, Aneka Hukum Perceraian di Indonesia, Ghalia Indonesia, Jakarta, 1982, h. 87. mungkin ada benda-benda yang tidak termasuk ke dalam kebersamaan atau gemeenschap, seperti benda-benda yang diperoleh secara cuma-cuma, dengan ketentuan dari pihak pewaris, atau penghibah atau schenker.

Asas sifat dan kebersamaan harta perkawinan terdapat dalam Pasal 119 BW, yang pada intinya menyatakan apabila tidak dibuat perjanjian kawin oleh calon suami-istri sebelum perkawinan dilangsungkan, maka akan terjadi kebersamaan harta kekayaan antara suami-istri itu karena undangundang. Oleh karena itu untuk memindahtangankan atau menjual harta tersebut harus dengan persetujuan keduanya atau menggunakan penetapan pengadilan apabila salah satu mengalami keadaan afwezigheid.

Menurut Henny Tanuwidjaja, akibat hukum keadaan afwezigheid terhadap harta apabila si yang tidak hadir kembali lagi: jika si yang tidak hadir kembali setelah masa pewarisan definitif, maka ia tetap mempunyai hak untuk meminta bagian sesuai hak warisnya kembali, termasuk hartanya yang terkemudian yang belum berpindah tangan, atau barang-barang yang saat dibeli dari uang hasil penjualan barang asal, namun dalam kesemuanya itu tanpa diperhitungkan terhadap hasil dan pendapatanpendapatannya (Pasal $486 \mathrm{BW}) .{ }^{15}$

Dalam keadaan afwezigheid apabila si yang tidak hadir kembali pada saat haknya sudah dipindahtangankan ke pihak lain maka saat itu juga akan daluwarsa haknya untuk meminta hartanya kembali. Untuk jangka waktu paling lama diatur dalam Pasal 484 BW tentang jangka waktu selama 30 (tiga puluh) tahun dari waktu penetapan pengadilan tentang afwezigheid dijatuhkan oleh Pengadilan Negeri.

\section{PENUTUP \\ Kesimpulan}

Dari penulisan di atas maka dapat disimpulkan bahwa ahli waris dalam arti sempit yang dimaksud dalam afwezigheid, yaitu suami atau istri serta anak-anak sah dan keturunannya. Perlindungan hukum yang diberikan kepada ahli waris terhadap warisan si yang tidak hadir adalah dengan penetapan pengadilan, sehingga untuk menjual harta si yang tidak hadir dapat berdasarkan penetapan pengadilan

\footnotetext{
${ }^{15}$ Henny Tanuwidjaja 2, Ibid., h. 7.
} 
yang menyatakan bahwa si yang tidak hadir diduga telah meninggal dunia.

Apabila suatu saat si yang tidak hadir ada kabar masih hidup atau kembali sesuai dengan jangka waktu yang telah diatur dalam undang-undang, maka ia dapat menuntut hak-hak atas harta yang ditinggalkan selama harta tersebut belum dipindahtangankan atau dijual oleh ahli warisnya. Hanya harta tetap yang beralih ke ahli warisnya, maka si yang tidak hadir tetap mempunyai hak atas harta asal tersebut, namun apabila harta tersebut telah dialihkan kepada pihak lain, maka pengalihan hak tersebut tidak dapat dituntut lagi oleh si yang tidak hadir.

Apabila suatu saat si yang tidak hadir ada kabar masih hidup atau kembali sesuai dengan jangka waktu yang telah diatur dalam undang-undang, sedangkan suami atau istri yang ditinggalkan belum melangsungkan perkawinan lagi, walaupun ia sudah mendapatkan penetapan pengadilan tentang afwezigheid, maka penetapan itu dapat dimintakan pembatalannya. Namun jika suami atau istri itu hendak bersatu lagi, tetapi yang ditinggalkan sudah terlanjur melangsungkan perkawinan dengan pihak lain, maka perkawinan yang baru tersebut tidak bisa dibatalkan dan si yang tidak hadir juga boleh melangsungkan perkawinan baru dengan pihak lain.

\section{Rekomendasi}

Pengadilan harus cermat untuk mengeluarkan penetapan afwezigheid agar si yang tidak hadir betulbetul memang sudah meninggal dunia.

\section{DAFTAR PUSTAKA}

Peraturan Perundang-undangan:

Kitab Undang-Undang Hukum Perdata (Burgerlijk Wetboek).

Undang-Undang Nomor 1 Tahun 1974 tentang Perkawinan.

\section{Buku:}

Hadjon, Philipus M., 1987, Perlindungan Hukum Bagi Rakyat Indonesia, Surabaya: Bina Ilmu.

Latif, Djamil, 1982, Aneka Hukum Perceraian di Indonesia, Jakarta: Ghalia Indonesia.

Mertokusumo, Sudikno, 1991, Mengenal Hukum (Suatu Pengantar), Yogyakarta: Liberty.

Prawirohamidjojo, R. Soetojo dan Marthalena Pohan, 2000, Hukum Orang dan Keluarga (Personen En Familie-Recht), Surabaya: Airlangga University Press.

Satrio, J., 1999, Hukum Pribadi Bagian 1 Persoon Alamiah, Bandung: Citra Aditya Bakti.

Tamakiran, 1992, Asas-asas Hukum Waris, Bandung: Pionir Jaya.

Tanuwidjaja, Henny, 2012, Hukum Waris Menurut $B W$, Bandung: Refika Aditama.

\section{Jurnal:}

Asari, Imam, "Kedudukan Orang Hilang Dalam Perspektif Kewarisan KUHPerdata (BW) dan Hukum Kewarisan Islam", Jurnal Ilmiah, Fakultas Hukum Universitas Mataram, 2012.

Tanuwidjaja, Henny, "Pewarisan Afwezigheid/ Keadaan Tidak Hadir dan Pewarisan Perkawinan Kedua Menurut Hukum Perdata Barat (BW)", Naskah Jurnal Hukum, yang diterbitkan Universitas Katholik Satya Wacana, 2016. 